\title{
The Criminal Law Enforcement Toward Violation of Environmental Permit
}

\author{
Endang Sutrisno*, Teddy Asmara, Junior Perdana Soetopo \\ Universitas Swadaya Gunung Jati \\ Cirebon, Indonesia \\ *endangsutrisno94@gmail.com,pascaunswagati16@gmail.com
}

\begin{abstract}
Environmental issues in the development of urban areas namely licensing become the main tools in the context of creating a sustainable environment. The implementation of criminal law enforcement for violations of environmental permits due to inconsistencies between regulations in terms of granting Building Permits has been applied through the aspect of the law enforcement instead of concerning the ambiguity in terms of texts in statutory regulations. However, focus more regarding the context in which the law grows and develops, namely in the community. The purpose of this study is to understand the application of environmental criminal sanctions, especially in terms of licensing aspects that can provide legal certainty. By using the juridical normative method, that legal norms have governed a good and healthy environment and constitute human rights and constitutional rights for every citizen. The reality of law enforcement regarding licensing issues in environmental law includes Amdal or UKL-UPL which must be owned by business actors or initiators of activities, as mandated through Law No.32 of 2009 concerning Environmental Protection and Management. These basic norms become the legal basis into technical regulations in the form of Regional Regulations as a local regulation that must be synchronous and harmonious with the existing regulations. Synchronization and harmonization of norms is an absolute prerequisite to ensure legal certainty which is the ultimate goal of the process of working with the law in the dynamics of social change.
\end{abstract}

Keywords: environmental law enforcement, synchronization, harmonization

\section{INTRODUCTION}

In every law enforcement, especially related to the environment, this results in the application of criminal sanctions, especially regarding licensing. This is fully realized because environmental issues are no longer seen in a partial approach, but have shifted to an integral-comprehensiveholistic approach. The government must be able to give affirmation to the community, the law that is made leads to the interests of the community and oriented towards social justice [1]. Indonesia today is faced with a very "unique" problem of law performance regarding the formal truth treated as the most dominant consideration of legal decision embracing reined Rechtslehre Kelsenian's way of thinking. An approach that is still in further discussion through a more holistic alternative paradigm [2].
The development with the utilization of the resources should be based on three pillars of sustainable development, like:

- Economically Viable;

- Socially Acceptable; and

- Environmentally Sound.

The development process carried out in this way is expected to obtain 2 (two) different results simultaneously, such as improving the social welfare and maintaining the quality of life of current and future generations. Law is an important element in the development of politics and it makes the relationship with government policy clearer. Through legislation, the Government determines what it can do and what not to do. Law defined as legislation is a system of norms where the rule of law is arranged in unity within a hierarchical manner. The lower legal norms should not be contradictory to the higher legal norms [3]. All development activities carried out in various forms of business and/or activities will basically cause environmental impacts. For that reason, by applying sustainable and environmentally sound principles as a control to the process of development, the impact on the environment caused by various development activities can be analyzed since initial planning, so that the steps to control negative impacts and develop positive impacts can be prepared from the beginning. The process of control to the implementation of development by prioritizing sustainable and environmentally sound principles is realized through instruments in the form of Environmental Impact Analysis (AMDAL) documents or Environmental Management and Environmental Monitoring Efforts (UKL-UPL) as one of the requirements to obtain Environmental Permit.

The legislator obliges business actors to have AMDAL instrument or UKL-UPL as the requirement of the Environmental Permit to run their business activities as regulated in Article 36 paragraph (1) of the UUPPLH. It states that "every business and/or activity is required to have an AMDAL or UKL- UPL must have an Environmental Permit ". Furthermore, Article 40 paragraph (1) of Law Number 32 Year of 2009 on Environmental Protection and Management states that an Environmental Permit is a requirement for obtaining a business and/or activity permit. Legal norms come in private sphere. It is as the argument that the law does not work in a vacuum. For this reason, social problems must be handled extraordinarily by law and must work in an extraordinary way 
[4]. Law enforcement refers to implementing the textual of legal norms in the social realities of society. The content of the substance of the norm is hoped to be clarified through legal behavior so that questions about legal awareness, legal compliance, legal feelings, and legal attitude will be more prominent [5].

As mentioned earlier, the criminal act on the environment is a crime against humanity, so law enforcement must prioritize criminal law enforcement along with administrative law enforcement and civil law, however in fact, there are factors that affect the enforcement, especially criminal law in environmental protection and management. One of them is disharmony between the UUPPLH and derivative regulations that create the emergence of criminogenic factors in law enforcement against violations of Environmental Permits. The disharmony among the existing regulations is that the provisions on Environmental Permits that are regulated in Article 36 paragraph (1) and Article 40 paragraph (1) of the UUPPLH, are carried out and implemented in line with derivative regulations such as Regional Regulations. The writers found a case in Regional Regulation of Cirebon City Number 4 of 2010 on Buildings where Regional Regulations are supposed to have a function as a gateway for a person or legal entity to run a business or activity by having a Building Permit (IMB) obtained through submitting an application to build a building to the Mayor through the Department that has the authority to issue Building Permit, but the fact the application does not require AMDAL or UKL-UPL documents and Environmental Permit. It is explained by Article 13 of Regional Regulation of Cirebon City No 4 of 2010 on The Building. For related efforts to realize an effective law system it is necessary to reorganize the legal institution, which is supported by qualified human resources and culture and a growing awareness of the community about law [6].

The purpose of the current study is focused on aspects of implementing criminal law enforcement based on applicable legal norms that are related to environmental legal rules concerning building permits and the application of environmental studies.

\section{METHODS}

The research approach used was a normative juridical approach. This emphasizes research into written legal norms in the form of text, namely Law Number 32 of 2009 concerning Environmental Protection and Management, and Cirebon City Regulation Number 4 of 2010 concerning Buildings, relating to Building Construction Permits, which must be completed with the Environmental Impact Analysis (AMDAL) or Environmental Management Efforts (UKL) and Environmental Monitoring Efforts (UPL) and Environmental Permits. The analysis concerned in this current study was legal material legislation products which included primary, secondary legal and tertiary legal materials. Data collection techniques were obtained through literature studies and interviews to examine the validity of the legal norms mentioned above.

\section{RESULTS AND DISCUSSION}

\section{A. The Criminal Law Enforcement on Violations to The Environmental Permit Provisions in Cirebon City}

In reality, the criminal law enforcement in Cirebon City is influenced by law enforcement factors in general. However, there are factors that contribute greatly to environmental criminal law enforcement related to violations of AMDAL or UKL UPL as a requirement for issuing Environmental Permit. The law as stated in Regional Regulation of Cirebon City Number 4 of 2010 on Buildings in Article 13 states:

The IMB application is submitted to the Mayor by attaching the following requirements:

- Photocopy of the applicant's identity card, and for the legal entity, it must be completed with the identity of the legal entity in the form of a legal entity establishment certificate;

- Power of attorney and a photocopy of identity card which is authorized in the case that the application is not made by the applicant himself;

- Photocopy of certificate of land rights or proof of land acquisition;

- Photocopy of payment of Land and Building Tax (PBB) payment for the latest year;

- Notification letter of no objection from neighbors for buildings used for business premises;

- Architectural drawings (floor plan visible and cut);

- Calculation of building construction for multi-story buildings;

- IMB and drawings of previous buildings if they intend to expand the building; and

- Declaration of ability to comply with the building's technical requirements in accordance with the building technical guidelines created.

With these provisions, the absence of AMDAL or UKLUPL documents as a requirement for the issuance of Environmental Permits for issuance of Building Construction Permits makes the business actors and officials have legal loopholes to issue Building Construction Permit without AMDAL or UKL-UPL documents, and Environmental Permit. As we know that Building Construction Permit is an important activity permit and is the basis for the issuance of further operational permits.

The provision in Article 97 of the UUPPLH states that "Criminal Act in this Law is a Crime". According to Tappan, "Crime" is a deliberate act or neglect in violating criminal law, done not for self-defense and without justification determined by the state. In short, crime as behavior and actions can be subject to sanctions that are formally determined by the state. With this explanation, because the nature of a criminal act in the UUPPLH is a crime, the enforcement of environmental criminal law must be carried out by prioritizing the principle of premium remidium, which means that enforcement of 
environmental criminal law is carried out simultaneously with administrative law enforcement and civil law enforcement, without waiting for the two other instruments becoming successful or unsuccessful in overcoming the problems. However, the existence of Regional Regulation of Cirebon City No. 4 of 2010 on Buildings has made a disharmony in the laws and regulations so it creates a state of Decriminalization to the aforesaid criminal provisions.

The Regional Government actually has duties and authorities in accordance with Article 63 paragraph 3 letter i of the UUPPLH, namely to provide guidance and oversight of compliance with business and/or activities to the environmental licensing provisions and legislation, but the Government of Cirebon City does not carry it out properly for their duties and authority. the violation of the provisions of the AMDAL and UKL-UPL as a requirement of the Environmental Permit is in accordance with Article 109 and Article 111 paragraph (1) and paragraph (2) of the UUPPLH being the duty of the police of Cirebon City to carry out criminal law enforcement by processing the perpetrators to the existing law. But the existence of Article 13 in Regional Regulation of Cirebon City Number 4 of 2010 on Buildings a gap for business men and officials, as well as intelligent advocates in defending their clients by using the arguments of above article, so it obstructs to enforce the regulation for violating the Environmental Permit through the Criminal Law instrument because of the existence of the problem of the Decriminalization of a criminal provision in the UUPPLH.

It is too difficult to solve environmental cases. There have been many attempts made by the government, community and environmental NGOs to bring cases to court. But the results achieved have not been encouraging environmentalists [7]. After the enactment of Law Number 23 Year 2014 concerning Regional Government and Law Number 9 Year 2015 concerning Second Amendment to Law Number 23 Year 2014 concerning Regional Government, in fact accelerated the exploitation of natural resources and the environment on a large scale which eventually left the principles of environmental safety, especially concerning ecological impacts [4].

The implementation of environmental law enforcement, especially environmental penalties for violations of environmental permits, can only be carried out when there is a strong desire from all stakeholders, both the regional government, law enforcers (police), and the community by equating the perception that the UUPPLH is made to regulate the sustainability of limited natural resources in order to future generations can use it. To overcome this problem, there must be harmonization between the existing regulations, especially those governing the Environment and Natural Resources, located on land, sea and air, at all levels of the Government, both at the Central, Provincial, and City and Regency levels. Human's life is dependent upon the natural environment, which, most would agree, is rapidly degrading. Business enterprises are a dominant form of social organization and contribute to worsening and enhancement, of natural environment [8].
B. Harmonization of Legislation to Overcome the Emergence of Criminogenic Factors among Regional Regulations in Cirebon City Related to Granting Permits to Build

Buildings with Environmental Protection and Management Efforts

In general, regulations are made with the aim of realizing the ideals of the nation and it is hoped that the legislators in formulating norms in a statute do not deviate from the goal so that each product of legislation in Indonesia will normally reflect the noble values that underlie the formation. According to Jimmly Assiddiqqie, every regulation in the formulation of the article must pay attention to:

- Religiosity of all citizens through the belief of all citizens towards God Almighty;

- The principles of fair and civilized humanity or the precepts of fair and civilized humanity;

- Guarantee and strengthen the principle of Indonesian nationality through the principle of Indonesian unity;

- Strengthening the values of people's sovereignty through popular precepts, led by wisdom in consultation/representation; and

- Institutionalize efforts to build social justice for all Indonesian people.

The logical consequence is that it is not possible to have laws that are made with the aim or it can have the effect of a new crime (criminogenic). when we look at the procedures in the formation of laws as contained in the Law of the Republic of Indonesia Number 12 of 2011 on the Formation of Laws in Article 1 number 1, it states that the formation of laws includes the stages of planning, preparation, discussion, endorsement or stipulation, and legislation. Furthermore, Article 6 of the UUP3 also states that the content of laws and regulations must reflect the principles of protection, humanity, nationality, kinship, nationality, unity in diversity, justice, equality of position in law and government, order and legal certainty, and/or balance, and harmony. These principles must flow into the articles of the legislation.

In Cirebon City, the enactment of Regional Regulation of Cirebon City Number 4 of 2010 on Buildings raises a criminal factor by providing a loophole for unscrupulous business actors and/or activities as well as officials to commit new criminal acts, namely the issuance of Business Permits and/or Permits for activities without the accompanying AMDAL or UKL-UPL documents and Environmental Permit required by UUPPLH. In accordance with the opinion of Zudan Arif Fakrulloh above, it can be ascertained by the enactment of the regulation that the victims are the environment and community. Although Amir Syarif stipulates the existence of five principles of law. One of them is the Hierarchy Level Principle or in Latin Lex Superior Derogate Legi Inferior (higher law overrides the lower law) but this does not remain the emergence of new problems namely criminogenic conditions due to the enactment of Regional Regulations.

In establishing a good legislation, there are at least 3 (three) foundations as follows: 1) Philosophical Foundation 
(Filosofishe Grondslag); 2) Sociological foundation (Sociologische Grondslag); 3) Juridical Foundation (Juridische Grondslag). According to Bagir Manan, the Juridical Foundation is very important in making legislation because it shows:

- Requirement of authority from the legislators. Every regulation of legislation must be made by an authorized official or agency;

- The necessity of conformity with the form of laws and regulations with the material regulated, especially if it is ordered by legislation of a higher level or equivalent;

- The obligation to follow certain procedures. If the procedure is not followed, the legislation may be null and void or does not / does not yet have binding legal force;

- The obligation does not contradict with the higher level regulations. A law may not contain rules that contradict the 1945 Constitution of the Republic of Indonesia, and so on until the lower level of legislation.

How far to the restoration project will move a system towards the guiding image will depend on many factors, some of which are non-ecological (e.g. existing infrastructure limitations, stakeholder needs and values, available funding) [9].

Talking about the existence of law as a system or interweaving of values has long been the center of attention of ancient philosophers. The existence of law is measured by the content of the presence or absence of value, specifically the value of justice. The law cannot be accepted as law if it does not contain an element of justice. The law cannot only be seen as a rational and abstract building, but the law has a broad dimension, including what is seen is a full social picture, which means entering various human and social dimensions into it. If the formation of a regulation is not in accordance with the philosophical foundation, sociological foundation, and juridical basis or hierarchy of legislation, there are 2 (two) kinds of rights to test the law as stated by Sri Soemantri in literature and practice, like:

- Formal Testing Right, is the authority to judge whether a legislative product such as a law has been made through the methods that have been regulated/determined in the applicable legislation or not;

- The Right to Test Material, is an authority to investigate and assess whether a regulation is in accordance with or contradictory to a higher degree of regulation, and whether a certain authority has the right to issue a certain regulation.

The provisions on AMDAL and UKL-UPL documents and Environmental Permits as stipulated in the UUPPLH in principle are a means to protect and manage the environment so that the implementation of sustainable development can go hand in hand between the needs of the community and the capacity of natural resources. Supervision through licensing is a preventive effort in the context of controlling environmental impacts. So that the rules on this Environmental Permit can run optimally, it is necessary to harmonize the lower regulations that have an impact on the environment directly or indirectly. Harmonization of Regional Regulation of Cirebon City Number 4 of 2010 on Buildings is conducted by testing in 3 (three) ways according to the opinion of Bagir Manan, like:

- Communities, in this case, social organizations or nongovernmental organizations engaged in the environment can conduct tests through a court with a judicial review to the Supreme Court on Regional Regulation of Cirebon City Number 4 of 2010 on Buildings with UUPPLH;

- The representatives of the community in this case the DPRD and the Mayor of Cirebon conduct tests to make changes or making new Regional Regulations to improve Regional Regulation of Cirebon City Number 4 of 2010 on Buildings; or

- Agency appointed by the UUPPLH for Environmental Protection and Management is the Ministry of Environment at the central level or the Environmental Agency at the regional level. They can conduct an administrative review to the Regional Regulation of Cirebon City Number 4 of 2010 on Buildings.

\section{CONCLUSION}

Disharmony between Cirebon City Regional Regulation Number 4 year 2010 concerning Buildings with Law No. 32 year 2009 concerning Environmental Protection and Management raises a criminal factor, namely the emergence of new criminal acts through legal loopholes that can be exploited by business actors and officials in issuing a Permit to set up a building without any Environmental Impact Assessment (AMDAL) document or Environmental Management Efforts (UKL) - Environmental Monitoring Efforts (UPL) and Environmental Permits. Implementation of harmonization in the Environmental Permit is a tool to observe the Government. Harmonization of legislative regulations regarding Environmental Permits is the key to carry out law enforcement through a mechanism that has been regulated in existing laws and regulations.

\section{REFERENCES}

[1] E. Sutrisno, "Relations Between Legal Culture and Economic Empowerment among Marginalized Group of Farmers", Journal of Legal, Ethical and Regulatory Issues, vol. 22, no. 3, pp. 22-3-329, 2019.

[2] E. Sutrisno, "Tracing the Performance of Law in Indonesia (A Perspective of Thomas Kuhn's "Normal Science", Journal of Law, Policy and Globalization, International Institute for Science, Technology \& Education Accelerating Global Knowledge Creation and Sharing, vol. 37, 2015.

[3] E. Sutrisno and I. Jazilah, "The Licensing Policy for Groundwater Extraction and Management for Hospitality Industry in Cities in Developing Countries", Journal Water Policy, IWA Publishing, vol. 21, no. 3, 2019

[4] E. Sutrisno, "Implementasi Pengelolaan Sumberdaya Pesisir Berbasis Pengelolaan Wilayah Pesisir Secara Terpadu Untuk Kesejahteraan Nelayan", Jurnal Dinamika Hukum, vol. 14, no.1, 2014. 
[5] E. Sutrisno, "The Study of River Pollution Related To Domestic Waste in the Perspective of Community Legal Culture", South East Asia Journal Of Contemporary Business, Economics And Law, vol. 12, 2017.

[6] E. Sutrisno, "The Legal Problem of Using Non Environmentally Friendly Fishing Gear in the Fisher Community of Indonesia," EurAsian Journal of BioSciences, vol. 13, no. 2, 2019.

[7] Immamulhadi, "Urgensi Pembentukan Peradilan Lingkungan Hidup", Jurnal Penegakan Hukum, vol. 4, no. 2, 2007.
[8] N.P. Melville and S.M. Ross, "Information Systems Innovation for Environmental Sustainability" Journal Society for Information Management Information Systems Research Center Mineapolis, vol. 34, no. $01,2010$.

[9] M.A. Palmer, "Standards for Ecologically Successful River Restoration, USA,” Journal of Applied Ecology British Ecological Society, 2005. 